Abstracta Iranica Abstracta Iranica

Revue bibliographique pour le domaine irano-aryen

Volume 26 | 2005

Comptes rendus des publications de 2003

\title{
Raskopki v Pajikende v 2002 gody. Saint Pétersbourg, Ermitage, 2003, 90 p. + 128 ill. [Fouilles de Paykent en 2002]
}

Étienne de La Vaissière

\section{(2) OpenEdition}

12 Journals

Édition électronique

URL : http://journals.openedition.org/abstractairanica/2707

DOI : 10.4000/abstractairanica. 2707

ISSN : 1961-960X

Éditeur :

CNRS (UMR 7528 Mondes iraniens et indiens), Éditions de l'IFRI

\section{Édition imprimée}

Date de publication : 15 mai 2005

ISSN : 0240-8910

Référence électronique

Étienne de La Vaissière, "Raskopki v Pajikende v 2002 gody. Saint Pétersbourg, Ermitage, 2003,

90 p. + 128 ill. [Fouilles de Paykent en 2002] », Abstracta Iranica [En ligne], Volume 26 | 2005, document 209, mis en ligne le 08 décembre 2005, consulté le 25 septembre 2020. URL : http://

journals.openedition.org/abstractairanica/2707 ; DOI : https://doi.org/10.4000/abstractairanica.2707

Ce document a été généré automatiquement le 25 septembre 2020.

Tous droits réservés 


\title{
Raskopki v Pajikende v 2002 gody. Saint Pétersbourg, Ermitage, 2003, 90 p. +128 ill. [Fouilles de Paykent en 2002]
}

\author{
Étienne de La Vaissière
}

1 Les travaux ont porté en 2002 sur 4 points principaux : à la citadelle (pp. 8-27), un puits a notamment été trouvé, le second pour toute une ville pour laquelle l'alimentation en eau a toujours été un problème ; au sharistan $\mathrm{I}$, où les fouilles ont à la fois porté sur le réseau des rues (pp. 27-32) et sur des maisons du Haut Moyen-âge (pp. 33-51) : il apparaît que la question du réseau des rues est beaucoup plus complexe que le schéma hippodamien envisagé jusqu'alors ; au sharistan II où un petit caravansérail urbain du $11^{\mathrm{e}} \mathrm{s}$. a peut-être été dégagé non loin d'un angle de la muraille (permettant un accès direct ?) (pp. 52-85).

INDEX

Thèmes : 4.1. Histoire médiévale

\section{AUTEURS}

ÉTIENNE DE LA VAISSIÈRE

ENS - Paris 